体育学研究, 35：133-142, 1990.

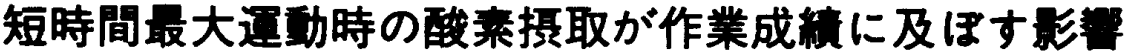

\author{
藤 瀬 武 彦1 玉 木 哲 朗1) 寺 尾 保1) \\ 永 見 邦 篤1) 中 野 昭 一1)
}

\section{Effect of oxygen uptake on performance during short-term strenuous exercise}

\author{
Takehiko Fujise ${ }^{1}$, Tetsuro Tamaki ${ }^{1}$, Tamotsu Terao ${ }^{1}$, \\ Kuniatsu Nagami ${ }^{1}$ and Shoichi Nakano ${ }^{1}$
}

\begin{abstract}
The purpose of this study was to investigate the effect of $\mathrm{NetVO}_{2}$ (excess increase to resting value) on performance during short-term strenous exercise in each sports event, and also the relationship between $\mathrm{NetVO}_{2}$ and $\mathrm{VO}_{2}$ max by using incremental exercise. Thirty-two trained males ( 100 m runners: $n=6,400$ m runners: $n=8$, ice hockey players: $n=10$, long distance sports men: $n=8$ ) and six untrained males, aged $23.6 \pm 3.1$ yrs, performed cycle ergometer exercise, pedaling against $0.1 \mathrm{kp} / \mathrm{kg}$ wt with maximal effort for $45 \mathrm{~s}$. $\mathrm{NetVO}_{2}$ in trained groups were significantly higher than that of untrained group. The differences of $\mathrm{V}_{2} \max$ between trained groups were significant, except between both groups of $400 \mathrm{~m}$ runner and ice hockey player, while there were no significant differences among $\mathrm{NetVO}_{2}$. Total work and peak power were highest in the groups of $100 \mathrm{~m}$ and $400 \mathrm{~m}$ runner, whose ratio of $\mathrm{NetVO}_{2}$ to $\mathrm{O}_{2}$ requirement were both $14.6 \%$, and this percentage was lowest in the five groups. The correlations between $\mathrm{NetVO}_{2}$ and total work were significant only in the groups of $100 \mathrm{~m}(\mathrm{r}=0.858: \mathrm{p}<0.05)$ and $400 \mathrm{~m}$ runner $(\mathrm{r}=0.857: \mathrm{p}<0.01)$. The correlations of $\mathrm{O}_{2}$ debt and total work, and $\mathrm{VO}_{2} \max$ and $\mathrm{NetVO}_{2}$ were significant in all subjects $(r=0.610, p<0.01 ; r=0.600, p<0.01)$, however, both relations were not significant in each group. These results suggest that in the athletes with high anaerobic capacity $\mathrm{NetVO}_{2}$ markedly contribute to perform a short-strenous exercise. In general, maximum oxygen uptake might be associated with an increase of $\mathrm{NetVO}_{2}$ during short-strenous exercise, but there was no relation between $\mathrm{NetVO}_{2}$ and $\mathrm{VO}_{2}$ max in the trained subjects.
\end{abstract}

(Japan J. Phys. Educ., 35: 133-142, September, 1990.)

\section{緒}

従来，短時間最大運動に対するェネルギーの 供給は，運動開始後40-50秒までは主として解 糖過程に依存し，60秒を経過すると有酸素的過 程からの供給が主体になるとされてい $3^{121,171,20)}$. したがって，約 1 分以内のいわゆる 無酸素的運動時の有酸素的エネルギ一供給の影 製についてはあまり注目されていなかった。

しかし, 近年, 短時間最大運動の作業成績に,
そのヒトの有酸素的作業能力が影䈉を及ぼすと の報告がなされた。すなわち, Ivy et al. $^{131}$ は Cybex II を用いた 45 秒間の脚伸展一屈曲運動 を行わせ，運動開始後 45 秒時の筋パワーと最大 酸素摂取量 (以下 $\dot{\mathrm{V}}_{2} \max$ とする) との間に有 意な相関を認めた。また，山本ら ${ }^{30} は 90$ 秒間の自 転車ペダリング運動で，運動開始後10秒以降の 筇出力と $\dot{\mathrm{V}} \mathrm{O}_{2} \max$ とが有意に相関することを 認めた。これらの成績から, 彼らは無酸素的運 動といえども，その運動の遂行に酸素利用能力
1）東海大学医学部生理学教室 下259-11 神奈川県伊愂原市望星台
1. Department of Physiology, School of Medicine, Tokai University,

Bohseidai, Isehara, Kanagawa (259-11) 
が影警を与えることを示唆した. 最近, 根本ら22) もこれらの成䌙を支持する報告を行っている。 しかし、これらの実験ではいずれも運動時の酸 素摄取量（以下 $\mathrm{VO}_{2}$ とする）を測定していない.

一方, Cunningham and Faulkner ${ }^{3 !}$ は, 1 分 程度で終了するトレッドミルランニングのト レーニング効果を検討し，その持続時間の向上 が, 無酸素的能力と運動開始後 30 秒以降の $\mathrm{VO}_{2}$ の増加によると報告した。 また，Thomson and Garvie の報告29)では，トレッドミルを用いたス プリントランニングを非鍛練者，マランン選手 および短距離選手に行わせ，運動開始後45秒ま での $\mathrm{VO}_{2}$ に差異がなかったことを示している。 これらの成絋は，短時間最大運動の場合，運動 開始後30-45秒までは，その作莱成紶に $\mathrm{VO}_{2}$ が ほとんど影響を及ぼさないことを示唆するとと もに，運動時の酸素摄取能力と $\mathrm{VO}_{2} \max$ や競 技特性とが，必ずしす网連していないことを推 測させる。

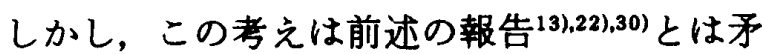
盾する。この理由のひとつとして，両者で運動 負荷法の異なっている点が挙げられる。すなわ ち，運動開始時から全力を強要した場合と，運 動強度が高水隼とはいえ，トレッドミルランニ ングのよらに一定強度を持続する場合とでは, エネルギー供給の過程, 筋疲労の発現やその推 移などが異なり，運動時の $\mathrm{VO}_{2}$ の関与も異なっ てくる可能性が考えられる。

そこで，本実験では，運動開始時から全力で

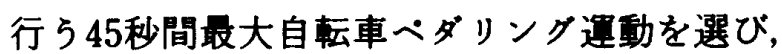

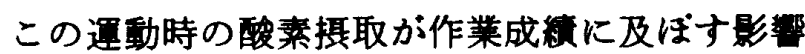
を検討した，特にこの両者の成係が競技特性の
異なる被験者各々で相違するか否かに着目し， 総仕事量と酸亲摂取是との成連を比較した。さ らに，無酸素的運動に最大酸素摄取能力が影響 を及ぼすとの報告13),22),30)を考虙し，短時間最大 運動時に拈ける酸素摂取量と $\mathrm{VO}_{2} \max$ との関 連る合わせて検討した。

\section{实 臤 方 法}

\section{A. 被赫者の㟟出}

被験者には，競技特性を考虑し，表 1 に示す よらな 5 群，計38名いずれも男性を選んだ。す なわち,

1. 陸上 $100 \mathrm{~m}$ 選手 6 名（ハイパワー持続鍛練 者(1)，以下 $100 \mathrm{~m}$ 群とする). $100 \mathrm{~m}$ の最高記録は 平均 $10.77 \pm 0.17$ (標準偏差) 秒である。

2. 陸上 $400 \mathrm{~m}$ 選手 8 名（ハイパワー持続鍛練 者(2)，以下 $400 \mathrm{~m}$ 群とする). $400 \mathrm{~m}$ の最高記録は 平均 $48.86 \pm 1.71$ 秒である。

なお，陸上短距離選手の最高記録が奄気計測 の場合には，その記録から0.24秒差し引いた記 録とした。

3.アイスホッケー選手10名（間欠的ハイハ ワ一鍛練者, 以下 $\mathrm{IH}$ 群とする)。競技歴 7 年以 上の東海大学フイスホッケー部員を選んた。

4. 長距離爱好者 8 名（持久的鍛練者, 以下 LD 群とする)。自転車ロード，マランンおよび トライアスロン要好者で, マランンの記録を有 する 2 名の平均最高記録は 2 時間 48 分 48 秒であ る.

5. 非鐉練者 6 名. 日常, 特別なトレーニング を行っていない者である。

表 1 に示した体脂肪率は, Brozek et al.の方

Table 1. Physical characteristics of five groups.

\begin{tabular}{lccccc}
\hline & $\begin{array}{c}\text { Age } \\
(\mathrm{yrs})\end{array}$ & $\begin{array}{c}\text { Height } \\
(\mathrm{cm})\end{array}$ & $\begin{array}{c}\text { Weight } \\
(\mathrm{kg})\end{array}$ & $\begin{array}{c}\text { Fat } \\
(\%)\end{array}$ & $\begin{array}{c}\text { LBM } \\
(\mathrm{kg})\end{array}$ \\
\hline 100m Runner(6) & $22.0 \pm 1.7$ & $173.6 \pm 4.2$ & $68.1 \pm 1.9$ & $12.1 \pm 1.6$ & $59.8 \pm 0.8$ \\
400m Runner(8) & $23.0 \pm 2.6$ & $172.4 \pm 4.6$ & $63.0 \pm 6.1$ & $10.6 \pm 1.3$ & $56.3 \pm 4.9$ \\
Ice hockey(10) & $20.1 \pm 1.2$ & $170.5 \pm 3.4$ & $60.9 \pm 3.2$ & $11.1 \pm 1.0$ & $54.1 \pm 2.8$ \\
Long distance(8) & $29.9 \pm 7.3$ & $169.0 \pm 5.0$ & $59.8 \pm 3.3$ & $11.5 \pm 1.7$ & $52.8 \pm 3.1$ \\
Untrained(6) & $23.5 \pm 2.9$ & $170.3 \pm 2.7$ & $67.4 \pm 4.8$ & $15.7 \pm 3.4$ & $56.7 \pm 2.8$ \\
\hline
\end{tabular}

Values are means $\pm \mathrm{SD}$. Values in parenthesis indicate number of subjects. 
法2゙により上腕背部および肩甲骨下部の皮脂厚 から算出した。なお，被験者には，実験を実施 するにあたり，その目的，方法および運動につ いて説明し，実験の意義を理解させるとともに 実験に参加する同意を得た。

\section{B. $\dot{\mathrm{V}} \mathrm{O}_{2} \max \sigma$ 測定}

ن $\mathrm{V}_{2} \max$ は, 自転車エルゴメーター（モナー ク社製)を用いた負荷漸増法，すなわち， $60 \mathrm{rpm}$ のペダリング頼度で $0.0 \mathrm{kp}$ から 1 分毎に0.5kp の負荷を增加させ, 疲労困想に至らしめる方法 で測定した。呼気は，ダクラスバッグ法により 採取し，標準ガスにて俥正した $\mathrm{O}_{2}$ フナライザー RAS-31および $\mathrm{CO}_{2}$ フナライザーRAS-41（AIC 社製）を用いてそれぞれ分析し， $\mathrm{VO}_{2}$ を算出し た。なお，標準ガスはあらかじめショランダー 散量ガス分析器にて検定した。 $\mathrm{VO}_{2} \max$ の判定 は, 1) 最高心拍数 $180 \mathrm{~b} / \mathrm{min}$ 以上, 2) $\mathrm{VO}_{2}$ の leveling off, 3）呼吸商 1.00 以上,などの基準を 指標とした。

C. 45秒间最大而的の角荷方法とパワーおよ び仕事悬の算出

運動負荷は，自転車エルゴメーターを用い， 体重 $1 \mathrm{~kg}$ 当り約 $0.1 \mathrm{kp}$ の負荷を基準とした。被 験者にはウォーミングフップを行わせず，直ち に45秒間終始最大努力のペダリング運動をサド ルから腰を上げずに行わせた。 パワーおよび仕 事量は，車輪回転に伴 5 on-off スイッチから 1

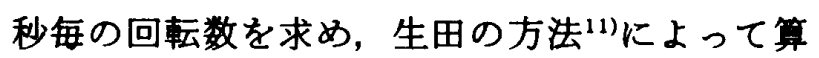
出した。

D. 45秒间最大而動における $\mathrm{VO}_{2}$ の測定 安静時 5 分間, 運動中 45 秒間および回復期 60
分間の $\mathrm{VO}_{2}$ を測定した。すなわち，安静時の呼 気は，食後 2 時間以上経過した被験者を 30 分間 仰卧させ，その25-30分の 5 分間採取した。運 動時の呼気は， $0-15 ， 15-30 ， 30-45$ 秒の各 期間 3 回採取した。回復期の呼気は, 運動終了 後直ちに被験者を仰臥させ，1 分後までの 1 分 間，次いで $1-3$ 分後までの 2 分間， $3-6$ 分 後までの 3 分間， $6-10$ 分後までの 4 分間，以 後，10-20分後までは 5 分間隔，20一60分後ま では10分間隔で採気し， $\mathrm{VO}_{2}$ を算出した。なお， $\mathrm{VO}_{2}$ の測定誤差を少なくするために，採気マス クからダグラスバッグまでの蛇管を $30 \mathrm{~cm}$ と し，運動時の採気には $50 l$ の小型ダグラスバッ グを使用した。運動時の $\mathrm{VO}_{2}$ から安静値を差し 引いた $\mathrm{VO}_{2}$ を以後 Net $\mathrm{VO}_{2}$ と表示する。

酸素負倩量 (以下 $\mathrm{O}_{2}$ debt とする) は, 安静時 の $\mathrm{VO}_{2}$ を基淮值として, 回復期60分間にこの値 を超過している $\mathrm{VO}_{2}$ とした，運動終了60分後も なお安静値に回復しなかった場合には，回復期 50一60分までの10分間の $\mathrm{VO}_{2}$ を基準値として $\mathrm{O}_{2}$ debt を算出しだ).

各群の各測定項目に打ける平均値の有意差検 定は, $\mathrm{t}$-検定により行い, $5 \%$ 水準以下を有意と した。

測定中の室温は $24.3 \pm 1.4^{\circ} \mathrm{C}$ ，気圧は757.3土 $6.9 \mathrm{mmHg}$ であった。

\section{实 験成赛}

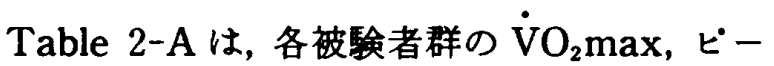
クパワーおよび総仕事量の値を示したものであ る。各测定項目について群間相互の有意差検定

Table 2-A. $\dot{\mathrm{VO}}_{2} \max$ by using incremental exercise, peak power and total work on 45 s maximal cycle ergometer pedaling.

\begin{tabular}{lccc}
\hline & $\begin{array}{c}\dot{\mathrm{VO}} \max \\
(\mathrm{ml} / \mathrm{min} / \mathrm{kg})\end{array}$ & $\begin{array}{c}\text { Peak power } \\
(\mathrm{kpm} / \mathrm{sec} / \mathrm{kg})\end{array}$ & $\begin{array}{c}\text { Total work } \\
(\mathrm{kpm} / \mathrm{kg})\end{array}$ \\
\hline 100m Runner(6) & $52.3 \pm 1.7$ & $1.51 \pm 0.11$ & $41.1 \pm 2.1$ \\
400m Runner(8) & $57.1 \pm 4.1$ & $1.41 \pm 0.10$ & $41.7 \pm 2.8$ \\
Ice hockey(10) & $57.2 \pm 3.2$ & $1.36 \pm 0.06$ & $38.6 \pm 1.8$ \\
Long distance(8) & $62.2 \pm 4.5$ & $1.29 \pm 0.15$ & $38.3 \pm 3.0$ \\
Untrained(6) & $45.0 \pm 3.8$ & $1.31 \pm 0.09$ & $34.1 \pm 2.2$ \\
\hline
\end{tabular}

Values are means \pm SD. Values in parenthesis indicate number of subjects. 
Table 2-B. Significant differences in $\mathrm{V}_{2} \max$, peak power and total work among each group.

\begin{tabular}{|c|c|c|c|c|c|c|c|c|c|c|c|c|}
\hline & \multicolumn{4}{|c|}{$\underset{(\mathrm{ml} / \mathrm{min} / \mathbf{k g})}{\dot{\mathrm{VO}_{2}} \max }$} & \multicolumn{4}{|c|}{$\begin{array}{l}\text { Peak power } \\
(\mathrm{kpm} / \mathrm{sec} / \mathrm{kg})\end{array}$} & \multicolumn{4}{|c|}{$\begin{array}{c}\text { Total work } \\
(\mathrm{kpm} / \mathrm{kg})\end{array}$} \\
\hline & 2 & 3 & 4 & 5 & 2 & 3 & 4 & 5 & 2 & 3 & 4 & 5 \\
\hline 1. $100 \mathrm{~m}$ Runner (6) & * & $* *$ & $*$ & * & ns & $* *$ & $* *$ & $* *$ & ns & * & ns & $* *$ \\
\hline 2. $400 \mathrm{~m}$ Runner (8) & & ns & * & * & & ns & ns & ns & & * & * & $* *$ \\
\hline 3. Ice hockey $(10)$ & & & * & ** & & & ns & ns & & & ns & * \\
\hline 4. Long distance (8) & & & & ** & & & & ns & & & & $*$ \\
\hline 5. Untrained (6) & & & & & & & & & & & & \\
\hline
\end{tabular}

Values in parenthesis indicate number of subjects. $2: 400 \mathrm{~m}$ Runner, $3:$ Ice hockey, $4:$ Long distance, 5 : Untrained. ns : not significant, significant level : ${ }^{*} \mathrm{p}<0.05,{ }^{*} \mathrm{p}<0.01$.

をした結果が Table 2-Bである. $\mathrm{VO}_{2} \max は$ は, LD 群が他の群に比較し有意に高値を示した。 次に IH 群と $400 \mathrm{~m}$ 群が続き，以下， $100 \mathrm{~m}$ 群， 非鍛練者群と有意に低い值であった。ピークパ ワーは, $100 \mathrm{~m}$ 群が IH 群, LD 群および非鍛綀 者群より有意に高値を示した。また，総仕事量 は, $100 \mathrm{~m}$ 群および400m 群で最も高く, IH 群お よびLD群がこれに続き，非鈠練者群が最も低 い値であった。

次に 45 秒間自転車ぺダリング運動時における 各群の各15秒毎の $\mathrm{NetVO}_{2}$ と, $\dot{\mathrm{VO}} \mathrm{O}_{2} \mathrm{max}$ に対す る各15秒毎の $\mathrm{VO}_{2}$ (安静時の $\mathrm{VO}_{2}$ を含む) の割 合（以下\% $\dot{\mathrm{VO}}_{2} \max$ とする）を Fig. 1 に示し た. NetVO より，15-30秒で $100 \mathrm{~m}$ 群 と $400 \mathrm{~m}$ 群より, 30一-45秒では他の 4 群よりもすべて有意に低值 を示した。 \% $\mathrm{VO}_{2} \max$ は, LD 群が15一30秒で非 鍛練者群と $100 \mathrm{~m}$ 群よりも，30-45秒で $100 \mathrm{~m}$ 群 よりも有意に少なかった。なお, $\mathrm{NetVO}_{2}$ と $\mathrm{VO}_{2}$ $\max$ との間には, 全被験者を一括した場合, 有 意な相関 $(\mathrm{r}=0.600: \mathrm{p}<0.01)$ が示された。し かし，各群毎に両者の関係をみると，いずれの 群にも有意な相関が認められなかった（100m 群 : $\mathrm{r}=0.021,400 \mathrm{~m}: \mathrm{r}=0.473$, IH 群 $: \mathrm{r}=$ $0.267, \mathrm{LD}$ 群 $: r=0.679$, 非鍛練者群 $: r=$ 0.705).

各群の $\mathrm{NetVO}_{2}, \mathrm{O}_{2}$ debt およびこれらの $\mathrm{O}_{2}$ 需要量に対する割合をFig. 2 に示した。 $\mathrm{Net} \mathrm{VO}_{2}$ は各鍛練者群が非鍛練者群よりも有意 に高値を示した。また， $\mathrm{O}_{2}$ debt は，各鉎練者群 が非鍛練者群より，100m 群および $400 \mathrm{~m}$ 群が LD 群よりも有意に高値を示した． $\mathrm{O}_{2}$ 需要量に 対する $\mathrm{NetVO}_{2}$ の割合は, LD 群が $17.2 \%$ と最 も多く, $100 \mathrm{~m}$ 群と $400 \mathrm{~m}$ 群がともに $14.6 \%$ と 5 群中最も少なかった。

Fig. 3 に, 各群の 45 秒間最大自転車ペダリン グ運動時の総仕事量と $\mathrm{NetVO}_{2}$, および $\mathrm{O}_{2}$ debt との関係を示した，総仕事量と $\mathrm{NetVO}_{2}$ との関 㐿は, 全被験者を一括した場合, 有意な相関 $(r=$ $0.721: \mathrm{p}<0.01 ）$ が示された. しかし, 各群毎 に両者の関係をみると，100m 群で $5 \%$ 水準， $400 \mathrm{~m}$ 群で $1 \%$ 水準で有意な相関が示されたも のの, 他の 3 群では有意な相関を認めなかった。 また, 総仕事量と $\mathrm{O}_{2} \mathrm{debt}$ との関係は, 全被験者 を一括した場合，有意な相関 $(r=0.610: \mathrm{p}<$ 0.01）が示された。しかし，各群毎に両者の関 係をみると，いずれの群でも有意な相関が認め られなかった。

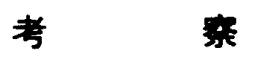

本実験では，ピークパワーおよび総仕事量が 高値を示した $100 \mathrm{~m}$ 群および400m 群の各群で, $\mathrm{NetVO}_{2}$ と総仕事量との間に正の相関関係がみ られた (Fig. 3)。そこで, $100 \mathrm{~m}$ 群および $400 \mathrm{~m}$ 群（以下短距離群とする）と他の 3 群とを比較 すると, 短距離群ほど $\mathrm{O}_{2}$ debt が多く, $\mathrm{O}_{2}$ 需要量 に対する $\mathrm{VO}_{2}$ の割合が低値を示した（Fig. 2). これは短距離群の方がより無酸素状態で運動を 遂行したことを示し，従来の成績とも一致し た1),10). 

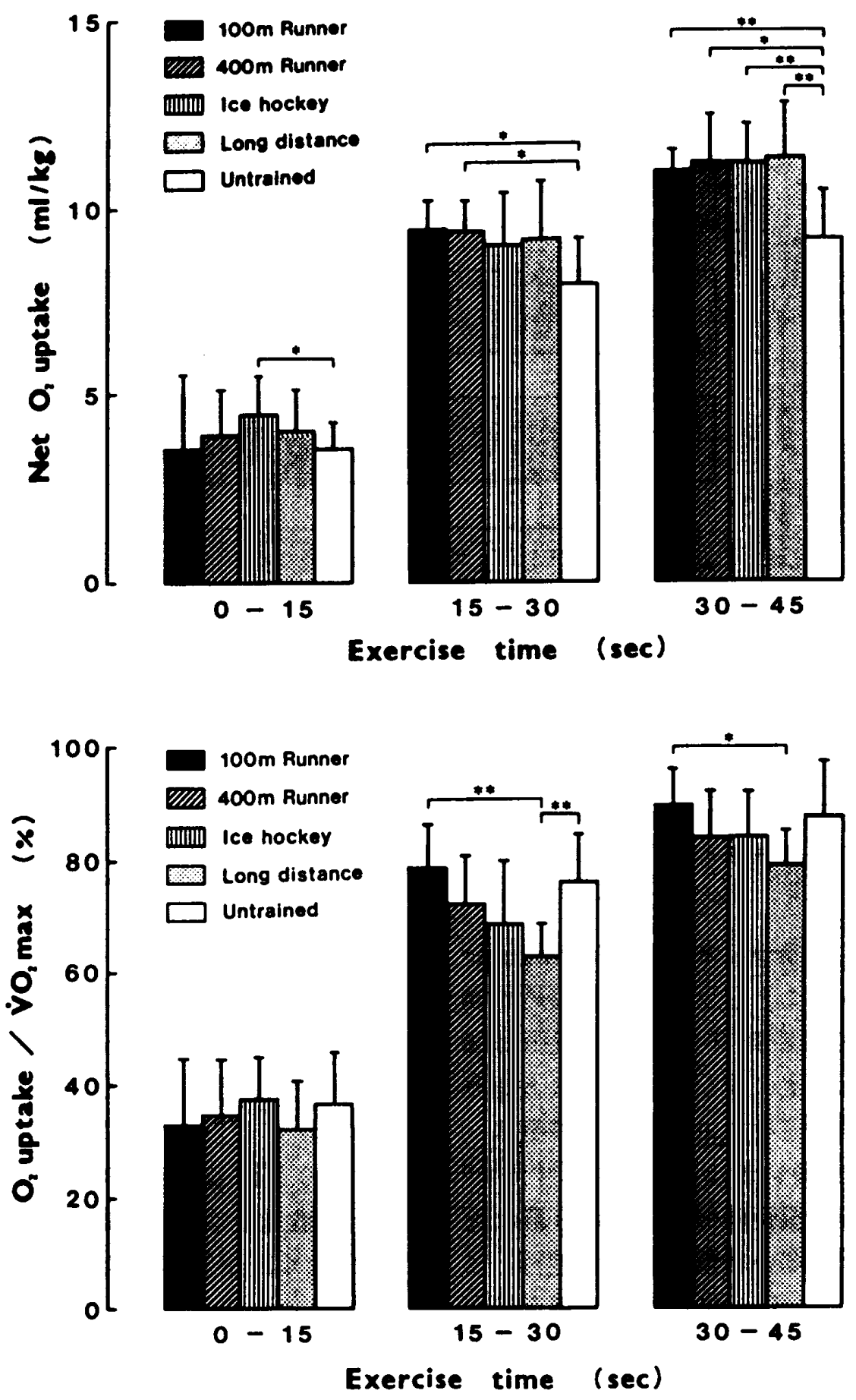

Fig. 1. $\mathrm{NetVO}_{2}$ (upper panel) and percentage of $\mathrm{O}_{2}$ uptake to $\mathrm{V}_{2} \max$ (lower panel) in each $15 \mathrm{~s}$ segments on $45 \mathrm{~s}$ maximal cycle ergometer pedaling. Values are means $\pm S D . *: p<0.05, * *: p<0.01$.

本実験では，血中乳酸を測定しなかった。し かし，既に報告した4)ように本実験と同一の運 動負荷条件下での最高血中乳酸値は14.5 $\mathrm{mmol} / l(130.2 \mathrm{mg} / \mathrm{dl})$ まで上㫒し，このときの 作業成績や $\mathrm{O}_{2} \mathrm{debt}$ (体重当りに換算) は，本実
験の短距離群の成績とほぼ一致した。 Jones et al. ${ }^{14)}$ は，最大アイソキネティックペダリング運 動 (60rpm および140rpm)を30秒間行わせたと き，血中乳酸值が約 $14-16 \mathrm{mmol} / l$ にまで達し， そのときの筋中乳酸値が $60 \mathrm{rpm}$ で $31.0 \pm 2.26$ 


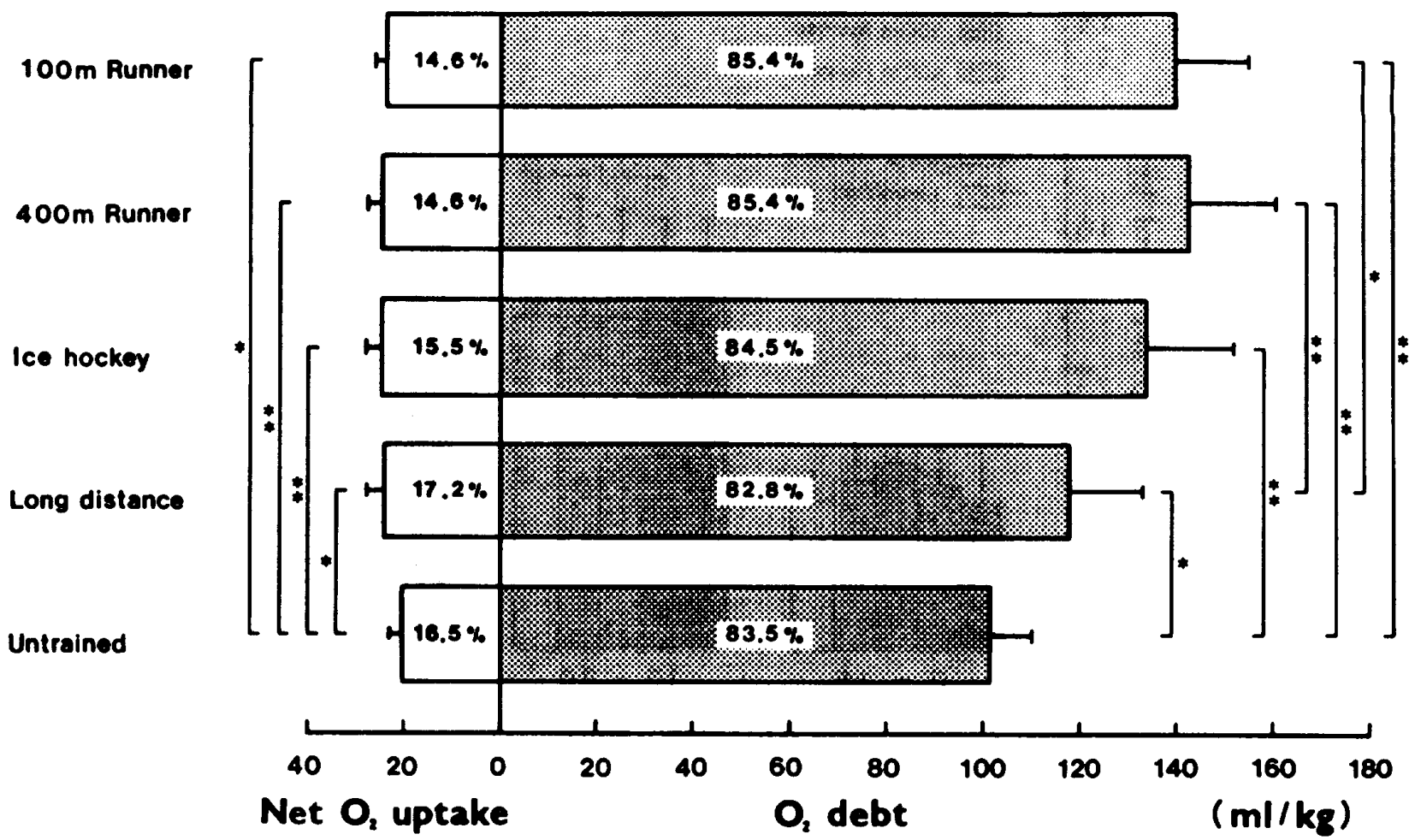

Fig. 2. $\mathrm{O}_{2}$ uptake and $\mathrm{O}_{2}$ debt in $\mathrm{O}_{2}$ requirement on $45 \mathrm{~s}$ maximal cycle ergometer pedaling. Values are means $\pm \mathrm{SD}$. Percentages in the columns indicate the ratio of $\mathrm{O}_{2}$ uptake and $\mathrm{O}_{2}$ debt in $\mathrm{O}_{2}$ requirement. $* \mathrm{p}<0.05, \cdots: \mathrm{p}<0.01$.

$\mathrm{mmol} / \mathrm{kg}$ wet wt, $140 \mathrm{rpm}$ で29.0 $1.99 \mathrm{mmol} /$ kg wet wt であったことを示した。これらの成 精から，本実検の短距離群の筇中乳酸值は30 $\mathrm{mmol} / \mathrm{kg}$ wet wt 程度に遼していたものと推測 される，短時間最大運動に上る血中乳酸値は， 仕事量や $\mathrm{O}_{2}$ debt が多い者はど高值を示す4),5),12) ことから，本実験の短距離群が，他の 3 群に比

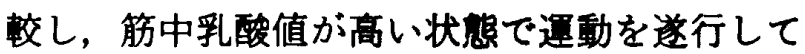
いたと推察される。一方，秏酸生成に伴5筋中 $\mathrm{pH}$ の变動が筋出力発揮を左右するとの指摘も ある ${ }^{23)}$. Tesch et $\mathrm{al}^{28}{ }^{28}$ は, 筋中乳酸値が22.2 $\mathrm{mmol} / \mathrm{kg}$ wet wt に達すると能出力の低下をむ たらすと報告した。乳酸蓄積に対する楥行能力 は, 非鍛練者よりす競技鍛練者の方が高く ${ }^{24)}$, 無 酸素的トレーニングによって増加する25). しか し，持久的銭練者とスプリントの鍜練者の緩衡 能力がほとんど変わらないとの報告すある21． これらのことから，筋出力低下をるたらすとさ れる高灌度の筋中乳酸レベル下での筋出力発揮 に際し，運動時の酸素撕取が有効になるのかむ
しれない.

45秒間最大運動時の $\mathrm{NetVO}_{2}$ には，機械的仕 事量への変換のみならず，ペダリング姿勢の保 持や呼吸運動による $\mathrm{O}_{2}$ 利用も包含されている ことが考えられる. Shephard ${ }^{26)}$ は, $80 \% \mathrm{VO}_{2}$ $\max$ の罢動強度のトレッドミル走を負荷した とき(換気量は89-130l/min である)，呼吸数に 関俰なく，全酸羑摄取量の約 $20 \%$ が呼吸筋に消 費されると報告した（本実験での短距離群の換 気量は101.8土25.7l/minであった)。また，玉木 と石河 ${ }^{271}$ は, $80 \% \mathrm{VO}_{2} \max$ の運動強度の自転車 ペダリング運動時における呼吸筋の酸素消費量 が，鍛練者で全酸素摄取量の $16 \%$ ，非鍛練者で $23 \%$ となったことを報告した。一方，30秒間の 最大運動終了時に, $\mathrm{VO}_{2}$ が $2.7 \mathrm{l} / \mathrm{min}$ まで上㫒 し，このときの大腿の動静脈酸素較差は $169 \mathrm{ml} /$ $l$ であったといら報告がある ${ }^{18)}$.一般に，この值 は筋の $\mathrm{O}_{2}$ 利用のほ注最大值と考兄られる。本実 倹の短距離群の場合, 運動開始後30から45秒ま での15秒間の $\mathrm{VO}_{2}$ は, $2.83 \pm 0.27 \mathrm{l} / \mathrm{min}$ であっ 


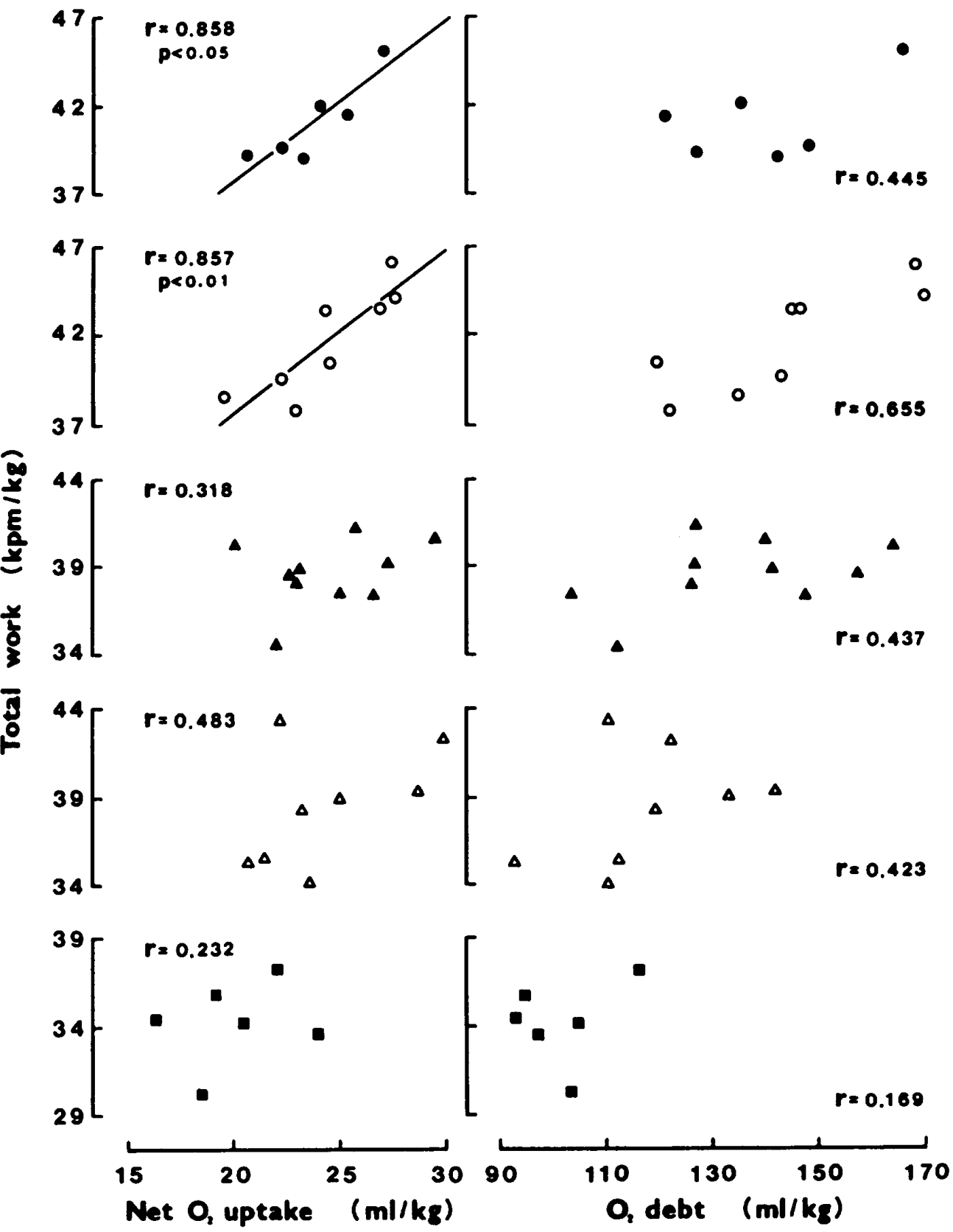

Fig. 3. Relationship between total work and $\mathrm{NetVO}_{2}$, and $\mathrm{O}_{2}$ debt on $45 \mathrm{~s}$ maximal cycle ergometer pedaling in each groups. Regression equation was determined by linear regression analysis. $\bigcirc: 100 \mathrm{~m}$ runners, $\bigcirc: 400 \mathrm{~m}$ runners, $\triangle$ : ice hockey players, $\triangle:$ long distance sports men, and $\mathbf{\square}$ untrained men, respectively.

た.したがって, NetVO住として自転車べダ リング運動の主動筋である大駺四頭筋などの下 肢筋群で利用されたるのと思われる。この $\mathrm{NetVO}_{2}$ 利用により全活動筋に対する相対的な 酸素不足が緩和され，乳酸蓄积の抑制や酸化過 程による ATP の生成をる招来して，高水準の パワー発揮を可能にしたとも推察される.
一般に $\mathrm{O}_{2} \mathrm{debt}$ は，無酸素的運動能力の指標 として测定されてきた ${ }^{10), 12), 19)}$. 本実験で行った $\mathrm{O}_{2}$ debt の算出方法による值は，既に報告しだ) よ5に安静時の $\mathrm{VO}_{2}$ のみを基準値として求め た值よりる14\%少なく見稓られるが（本実検で は, 平均 $18 \%, 100 \mathrm{~m}$ 群 $-27.3 \mathrm{ml} / \mathrm{kg}, 400 \mathrm{~m}$ 群 $-20.4 \mathrm{ml} / \mathrm{kg}$, IH 群 $-21.4 \mathrm{ml} / \mathrm{kg}, \mathrm{LD}$ 群一 18.8 
$\mathrm{ml} / \mathrm{kg}$ ，非鍛練者群一 $29.9 \mathrm{ml} / \mathrm{kg}$ ，それぞれ少な かった），作業成績とより高い相関を示す。本央 験でも全被験者を一括した場合, $\mathrm{O}_{2} \mathrm{debt}$ と総仕 事量との間に有意な相関 $(r=0.610: p<0.01)$ が認められた。しかし，Fig. 3 で示したように， 各群每の両者の関係は，有意ではなかった。 Hermansen ${ }^{9}$ は, $\mathrm{O}_{2}$ debt が運動能力の指標とし て，競技鍛練者と非鍛練者などの群間の区別に 用いることができると述べている。換言すれば， $\mathrm{O}_{2}$ debt と作業成績との関俰が同じ競技者や運 動能力の同等な者どうし間で比較しても明確に ならないことを示唆している，また，本実験条 件では， $\mathrm{O}_{2}$ 需要量に対する $\mathrm{O}_{2} \mathrm{debt}$ の占める割 合が約 $85 \%$ と量的には $\mathrm{NetVO}_{2} よ り$ 多いが (Fig. 2)， $\mathrm{O}_{2}$ debt および $\mathrm{Net} \mathrm{VO}_{2}$ の運動遂行の ための貢献度をFig. 3 に示した相関関係から 比較すると，それはほぼ同等であるよらに思わ れる。

$\mathrm{NetVO}_{2}$ は, $100 \mathrm{~m}, 400 \mathrm{~m}, \mathrm{IH}$ および LD 群な ぞの鉎練者群の方が非鍛練者群より有意に高 かった(Fig. 2). $\mathrm{VO}_{2} \max$ を鍛練者群間で比較 すると, Table 2-Bで示したように, 400m 群と IH 群間を除くいずれの群間にも有意差が認め られた。一方, 鍛練者群間で $\mathrm{NetVO}_{2}$ を比較する と，いずれも有意差を認めなかった (Fig. 1). また， $\mathrm{Net} \mathrm{VO}_{2}$ と $\mathrm{VO}_{2} \max$ との関係は，全被験 者を一括した場合，有意 $(r=0.600: p<0.01)$ であったものの，各群毎に両者の関係をみると いずれの群も有意ではなかった。これらのこと は，鍛練者の場合， $\mathrm{NetVO}_{2}$ と $\mathrm{VO}_{2} \max$ との関 連性が少ないことを示唆している。しかし，小 林と天野 ${ }^{16}$ は，30および60秒間の最大自転車ぺ ダリング運動時の $\mathrm{VO}_{2}$ が, $\mathrm{VO}_{2} \max$ の高い中・ 長距離選手群の方で，その絶体値および体重当 りの量とも短距離選手群より高値であったこと を報告しており，本実験の成績とは異なってい た。この原因のひとつに，運動方法の違いが考 えられる，すなわち，前者では，パワーを一定 に発揮できるような条件下（アイソパワー）で 運動を行わせており，本実検ではパワーが運動 開始後 4-7 秒でピークに達し，運動終了時点
（45秒後）で約 $60 \%$ 低下する運動条件であった。 また，Wingate test（30秒間の最大自転車ぺダ リングテスト）の場合, Kavanagh et al. ${ }^{151}$ は $\mathrm{VO}_{2} \max の$ 高い被験者の方が相対的な有酸素 的エネルギーの貢献度が高いと報告した。しか し, 吉田ら ${ }^{31)}$ は, 持久能力によって運動開始後の $\mathrm{VO}_{2}$ 応答特性が变化することはなかったと報告 し，一致した見解が得られていない。この原因 として，用いた被験者の違いが考えられる。す なわち，前者で用いた被験者は，健康な男性ボ ランティアでその $\mathrm{VO}_{2} \max$ 範囲が比較的大 きい $(45.1-58.3 \mathrm{ml} / \mathrm{kg} / \mathrm{min})$ が, 後者では, 被験者として女子陸上中長距離選手を用いてお。 り，その $\mathrm{V}_{2} \max$ は記載されていないが，身体 特性が似ていたものと思われる。

いずれにしても，本実験の成績は，特に鍛練 者において短時間最大運動時の酸素摂取能力 が，負荷漸増運動による最大酸素摄取能力とは 必ずしも一致しないことを示唆している，その 原因のひとつとして，45秒間最大運動と $\dot{\mathrm{VO}}_{2}$ max 測定のための負荷漸増運動との運動強度 の相違が挙げられる。最大下運動の場合には, $\dot{\mathrm{VO}}_{2} \mathrm{max}$ の高い被検者ほど, 運動開始後の $\dot{\mathrm{VO}}_{2}$ 応答がより速いことが知られている77,8)。 しか し，本実験条件の場合，45秒間の最大自転車ぺ

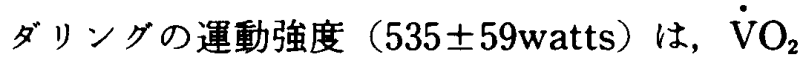
max 測定時（負荷漣増運動終了時点）の運動強

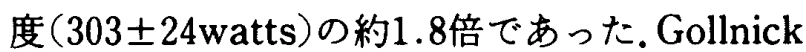
et $a{ }^{6}{ }^{6}$ は, 自転車ペダリングの運動強度の違い によって，大腿四頭筋の FT と ST 線維におけ るグリコーゲンの减少パターンが異なると報告 している。このことは，45秒間最大運動と負荷 漸増運動とでは，動員される筋線維タイプや筋 量の相違することを伺わせ，それが $\mathrm{NetVO}_{2}$ と $\mathrm{VO}_{2} \max$ との間に有意な相関の認められな かった一因として考虑されるべきかもしれな い.さらに, $\mathrm{LD}$ 群の\% $\mathrm{VO}_{2} \max$ は他の群に比べ て最も低值であった (Fig. 2).このことも負荷 漸増運動で測定した $\mathrm{VO}_{2} \max か ゙ ，$ 短時間最大 運動時の酸素摄取量と関連性の少ないことを示 唆している。 


\section{ま と ぬ}

本実験は, 短時間最大運動時の酸素摂取が作 業成績に影響を及ぼすか，特にこの両者の関係 が競技特性により相違するか否かを明らかにす ること，さらに運動時の酸素摂取量と $\dot{\mathrm{VO}}_{2} \max$ との関連も合わせて検討することを目的とし た。被験者は，鈠練者 32 名(陸上 $100 \mathrm{~m}$ 選手 6 名, 陸上 $400 \mathrm{~m}$ 選手 8 名, アイスホッケー選手 10 名, 長距離愛好者 8 名）および非鐉練者 6 名いずれ も男性 (23.6土3.1歳)を選び，彼らに45秒間最 大自転車ペダリング運動を負荷し，総仕事量と 酸素摂取量との関連を比較検討した。その結果,

1. $\dot{\mathrm{VO}}{ }_{2} \max$ は, LD 群 $(62.2 \pm 4.5 \mathrm{ml} / \mathrm{min} /$ $\mathrm{kg}$ ）が他の群に比較し有意に高値を示した。次 に IH 群 $(57.2 \pm 3.2 \mathrm{ml} / \mathrm{min} / \mathrm{kg})$ と $400 \mathrm{~m}$ 群 $(57.1 \pm 4.1 \mathrm{ml} / \mathrm{min} / \mathrm{kg})$ がほぼ同値で続き，以 下, $100 \mathrm{~m}$ 群 $(52.3 \pm 1.7 \mathrm{ml} / \mathrm{min} / \mathrm{kg})$, 非鍜練者 群 $(45.0 \pm 3.8 \mathrm{ml} / \mathrm{min} / \mathrm{kg})$ と有意に低值を示し た。

2. 総仕事量は, $100 \mathrm{~m}$ 群 $(41.1 \pm 2.1 \mathrm{kpm} / \mathrm{kg})$ と $400 \mathrm{~m}$ 群 $(41.7 \pm 2.8 \mathrm{kpm} / \mathrm{kg})$ がほぼ同值で最 も高値を示し, 次に $\mathrm{IH}$ 群 $(38.6 \pm 1.8 \mathrm{kpm} / \mathrm{kg})$ と $\mathrm{LD}$ 群 $(38.3 \pm 3.0 \mathrm{kpm} / \mathrm{kg})$ がほぼ同値で続 き，非鍛練者群 $(34.1 \pm 2.2 \mathrm{kpm} / \mathrm{kg})$ が最も低 值を示した。

3. 最大運動時の $\mathrm{NetVO}_{2}$ は, 各鍜練者群が非 鍛練者群より有意に高値を示したが，鍛練者群 間ではいずれす有意差を認めなかった。

4. $\mathrm{O}_{2}$ 需要量に占める $\mathrm{VO}_{2}$ の割合は, $100 \mathrm{~m}$ 群 および $400 \mathrm{~m}$ 群がともに $14.6 \%$ で最も少なく， 次に IH 群が $15.5 \%$, 非鍛練者群が $16.5 \%$ と続 き，LD 群が $17.2 \%$ と最も多かった。

5. $\mathrm{NetVO}_{2}$ と総仕事量との関係は, 全被験者 を一括した場合，有意な相関（ $\mathrm{r}=0.721 ： \mathrm{p}<$ 0.01）を示した。しかし，各群毎に両者の関俰 をみると，100m 群および $400 \mathrm{~m}$ 群でのみ，有意 な相関 $(\mathrm{r}=0.858: \mathrm{p}<0.05, \mathrm{r}=0.857: \mathrm{p}<$ 0.01) が認められたものの，他の群においては 有意ではなかった。

6. $\mathrm{O}_{2}$ debt と総仕事量との関係は, 全被験者
を一括した場合，有意な相関（ $r=0.610 ： p<$ 0.01）を示した。しかし, 各群每に両者の関係 をみると，いずれの群でも有意ではなかった。

7. $\mathrm{Net}_{\mathrm{VO}_{2}}$ と $\mathrm{VO}_{2} \max$ との関係は, 全被験 者を一括した場合，有意な相関 $(r=0.600: \mathrm{p}<$ 0.01）を示した。しかし，各群毎に両者の関係 をみると、いずれの群でも有意ではなかった。

以上の成績から，短時間最大運動を行わせた 場合，無酸素的作業能力が高い競技者では，運 動時の酸素摄取量の作業成績に与える影響が比 較的大きいことが示唆された。また，一般に $\dot{\mathrm{V}} \mathrm{O}_{2} \max$ は短時間最大運動時の酸素摄取量に 影響を及ぼすが，競技鍛練者においては，両者 の関連性はなかった。

\section{引用・参考文献}

1）青木純一郎・形本静雄 $\Gamma 100 \mathrm{~m}$ 走における疾走時間と 非乳酸性および乳酸性負債について」昭和47年度日 本体育協会スボーツ科学研究報告：3-11, 1972.

2) Brozek, J., Grande, F., Anderson, J.T. and Keys, A., "Densitmetric analysis of body composition : revision of same quantitative assumptions," Ann. N.Y. Acad. Sci., 110 : 113-40, 1963.

3) Cunningham, D.A. and Faulkner, J.A., "The effect of training on aerobic and anaerobic metabolism during a short exhaustive run," Med. Sci. Sports, 1:65-69, 1969.

4）藤瀬武彦・玉木哲朗・寺尾 保・中野昭一「血中乳 酸値および酸素負倩量による無酸素的運動能力評 価法の検討」体力科学, 38:85-94, 1989.

5) Fujitsuka, N., Yamamoto, T., Ohkuwa, T., Saito, M. and Miyamura, M., "Peak blood lactate after short periods of maximal treadmill running," Eur. J. Appl. Physiol., 48: 289-96, 1982.

6) Gollnick, P.D., Piehl, K. and Saltin, B., "Selective glycogen depletion pattern in human muscle fibres after exercise of varying intensity and at varying pedalling rate," J. Physiol. (Lond.), 241 : 45-57, 1974.

7) Hagberg, J.M., Nagle, F.J. and Carlson, J.L., "Transient $\mathrm{O}_{2}$ uptake response at the onset of exercise," J. Appl. Physiol., 44 : 90-92, 1978.

8) Hickson, R.C., Bomze, H.A. and Holloszy, J.O., "Faster adjustment of $\mathrm{O}_{2}$ uptake to the energy requirement of exercise in the trained state," J. Appl. Physiol., 44 : 877-91, 1978.

9) Hermansen, L., "Anaerobic energy release," 
Med. Sci. Sports, $1: 32-38,1969$.

10）猪铜道夫・生田香明・岛岡清「パー発揮能力・ 持繶能力の酸来負僙且の面からの探究」昭和 46 年度 日本体育協会スポーツ科学研究報告：4-15, 1971.

11）生田香明,「モナーク製自枟車エルゴメーターによ る anaerobic power の测定法」身体㯰峌の科学 I， human power の研究, 杏林青院, 1972, pp. 45-62.

12）生田香明・猪铜道夫「Mechanical power，血液乳酸

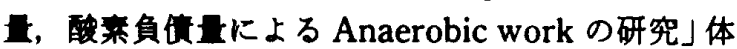
力科学, $22: 1-8,1973$.

13) Ivy, J.L., Sherman, W.M., Miller, L.M., Maxwell, B.D. and Costill, D.L. "Relationship between muscle $\dot{\mathrm{Q}}_{2}$ and fatigue during repeated isokinetic contractions," J. Appl. Physiol., $53: 470$ $-74,1982$.

14) Jones, N.L., McCartney, N., Graham, T., Spriet, L.L., Kowalchuk, J.M., Heigenhauser, G.J.F. and Sutton, J.R., "Muscle performance and metabolism in maximal isokinetic cycling at slow and fast speeds," J. Appl. Physiol., 59 : 132-36, 1985.

15) Kavanagh, M.F. and Jacobs, I., "Breath-bybreath oxygen consumption during performance of the Wingate test" Can. J. Spt. Sci., 13: 91-93, 1988.

16）小林宽道・天野童裕「無酸莱性および有酸莱性ハ ワー発挥能力の相互作用に目する研究」昭和60年度 日本体育協会スボーツ医・科学研究埌告：21-30, 1985.

17) Keul, J., Doll, E. and Keppler, D., "Energy metab. olism of human muscle," Medicine and Sport, 7 : S. Karger, Basel, 1972.

18) Kowalchuk, J.M., "Acid-base balance and metabolism in short-term maximal exercise," Hamilton, Ont. : McMacter University, 1985.(Ph D thesis)

19）黑川隆志・吉相泰一・野村武男・池上晴夫「畏大酸

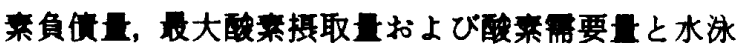
記録との肉係」体育学研究, $29: 295-305,1985$.

20) Margaria, R., Cerretelli, P. and Mangili, F., "Balance and kinetics of anaerobic energy release during strenuous exercise in man," J. Appl. Physiol., $19: 624-28,1964$.

21) Medb $\phi$, J.I. and Sehersted, O.M., "Acid-base and electrolyte balance after exhausting exercise in endurance-trained and sprint-trained subjects," Acta Physiol. Scand., 125 : 97-109, 1985.

22）根本 夏・金久博昭・福永哲夫 - 角田直也・下数領 光一・吉岡伸彦・宮下充正「取大有酸亲性バ 等速性筇出力との同俰」体力科学, $37: 77-84,1988$.

23) Sahlin, K., "Muscle fatigue and lactic acid accumulation," Acta Physiol. Scand., 128(Suppl., 556) : 83-91, 1986.

24) Sahlin, K. and Henriksson, J., "Buffer capacity and lactate accumulation in skeketal muscle of trained and untrained men" Acta. Physiol. Scand., $122: 331-39,1984$.

25) Sharp, R.L., Costill, D.L., Fink, W.J. and King, D. S., "The effects of eight weeks of bicycle ergometer sprint training on buffer capacity," Int. J. Sports Med., $7: 13-17,1983$.

26) Shepherd, R.J., "The oxygen cost of breathing during vigorous exercise," Quart. J. Exper. Physiol., $51: 336-50,1966$.

27）玉木伸和・石河利宽「毁㙌者および非鈠梀者の運動

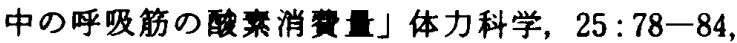
1976.

28) Tesch, P., Sjodin, B., Thorstensson, A. and Karlsson, J., "Muscle fatigue and its relation to lactate accumulation and LDH activity in man," Acta Physiol. Scand., 103 : 413-20, 1978.

29) Thomson, J.M. and Garvie, K.J., "A laboratory method for determination of anaerobic energy expenditure during sprinting," Can. J. Appl. Spt. Sci., $6: 21-26,1981$.

30）山本正重・中村好男・宮下充正「90秒間連絖の报大

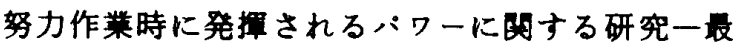
大無酸莱性バワーおよび最大有酸菜性パワーとの 米連から一」J.J. Sports Sci., 4 : 308-13, 1985.

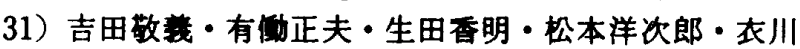
幸作・中营二三生「Wingate Anaerobic Test 中お よび回復時の breath-by-breath 测定によるガス交 換ハラメーターの特性について」体力科学, $37: 493$, 1988.

（平成元年 9 月 11 日受付） 